\title{
The Role of Tourism on Local Economic Development of Gondar City, Amhara Regional State, Ethiopia
}

\section{Nurhssen $\mathbf{S}^{*}$}

Department of Agricultural Economics, University of Gondar, Ethiopia

\begin{abstract}
Tourism is an ever expanding service industry with latent vast growth potential and has, therefore, become one of the largest and dynamically developing sectors of nations. Its capacity to generate employment both directly and indirectly, its potential to earn foreign currency for the host community, its high growth and development rates, infrastructure development, introduction of new management and educational experience, have made this industry greatly desirable for all. The outcome of increasing tourism has been found to be a critical and crucial catalyst in accelerating the rate of socio-economic development. Therefore, the study entitled the role of tourism to local economic development of Gondar city in terms of income receipt, job opportunity expansion and investment attraction was undertaken. To scrutinize the role of the sector in the city, the study used 150 samples randomly those are directly impacted by the tourism sector. In order to gather the necessary data from the sample those directly impacted by the tourism sector, questionnaire and interview were used as research instrument tools. In light of this, descriptive statistics was employed to analyze the data obtained through questionnaire. The study finding indicates that tourism sector is crucial armed force in fighting and reducing the extent and intensity of poverty in general. Besides, the society`s livelihoods were improved significantly. More specifically, the employment of those who joined the sector as government employee has increased from 2000 employees in 2011 and increases to 4800 in 2015 and the number of employees engaged in hotels, restaurants, pensions, lodges etc. revealed that there are about 5500 persons employed excluding other indirect employees and the income level increased from birr 80,000 and birr 300,000 in 2007 to birr 1,230,000 and 7,768,019 in 2015 from domestic and foreign tourists respectively.
\end{abstract}

Keywords: Employment; Foreign currency; Tourism; Gondar; Income receipt; Poverty; World tourism; Travel council; Investment

\section{Introduction}

\section{Background of the study}

Today, tourism is one of the largest and dynamically developing sectors of the world. Its high growth and development rates, considerable volumes of foreign currency inflows, infrastructure development, and introduction of new management and educational experience actively affect various sectors of economy, which positively contribute to the social and economic development of the country as a whole [1].

According to World Tourism and Travel Council [2], tourism provides about 9.8 percent of global gross domestic product (GDP) and 10 percent of the world's income and 9.4 percent of employment worldwide, receipts account for a little over 5.7 percent of world export and 4.3 percent of total investment. Many people emphasize the positive aspects of tourism as a source of foreign exchange, a way to balance foreign trade, an "industry without chimney"-in short, manna from heaven [3].

The number of international arrivals increased from 25 million in 1950 to about 940 million in 2010 and 1.14 billion in 2014 and visitor spending more than matched that growth. Visitors from emerging economies now represent a $46 \%$ share of these international arrivals (up from 38\% in 2000), proving the growth and increased opportunities for travel from those in these new markets [4].

Tourism is a fast growing and leading export economic sector internationally though the lion's share goes to the developed hemisphere both in terms of arrival and corresponding receipt. The growth rate, however, is higher in the developing countries. Based on Overseas Development Institute [5], though the share of Africa from world tourism is very low tourism in Africa, particularly south of the
Sahara, showed an increasing trend. Tourism and travel in Africa accounts for 8.1 percent of GDP, 7.1 percent of total employment and 5.9 percent of total investment [4].

Governments in Africa are showing increasing interest to tourism as a source of growth and diversification. Recent work indicates that tourism in Africa can, in the right circumstances, contribute effectively to economic development because: Barriers to entry into the international market are lower than for most external trade sectors; Tourism expenditures can provide a significant stimulus to other production and service sectors. Properly managed tourism has the potential to alleviate poverty, preserve cultural heritage and protect natural resources; and International tourism is a relatively high-growth industry [6].

Travel and tourism in Ethiopia contributes much to the country's GDP, employment, investment etc. Tourism is a featured component of Ethiopia's Poverty Reduction Strategy Paper (PRSP) that aims to combat poverty and encourage development in the country.

Because of the unique feature of the land in terms of natural cultural historical and religious tourism assets and unique biodiversity, Ethiopia has a big potential for tourism. According to WTTC [4], tourism contributes 35.4 percent of total export in Ethiopia. The

${ }^{*}$ Corresponding author: Nurhssen S, Department of Agricultural Economics, University of Gondar, Ethiopia, Tel: +251 92846 7384; E-mail: snurhssen@gmail.com

Received February 25, 2016; Accepted August 08, 2016; Published August 12 2016

Citation: Nurhssen S (2016) The Role of Tourism on Local Economic Development of Gondar City, Amhara Regional State, Ethiopia. J Glob Econ 4: 207. doi: 10.4172/2375-4389.1000207

Copyright: (c) 2016 Nurhssen S. This is an open-access article distributed unde the terms of the Creative Commons Attribution License, which permits unrestricted use, distribution, and reproduction in any medium, provided the original author and source are credited. 
number of travelers to Ethiopia showed increment since the time of Minilik II. However, tourism recognized as an important economic sector late in 1961 when an organization concerned with tourism environment was established [7].

Ethiopia is one of the countries that have enormous and diverse tourist attractions. It has beautiful land features ranging from the highest mountain, Ras Dashen, to Dankal depression, one of the lowest points in the world, consisting of different attractive rivers having water falls, lakes including the Rift valley lakes, and the various caves like Sofomor (the largest cave in Africa). This wide land features gave birth to the different ecological zones that are a home for the wide variety of wild life of both fauna and flora. Ethiopia is rich enough in wild animals including the seven species of Mammals and twenty five species of birds that are endemic to Ethiopia.

The city of Gondar, in Northern Ethiopia, has won the prestigious status of a classified UNESCO world heritage site, in 26 October 1979, mainly because in it stands the castle compound locally known as the Atsie Fasil Ghimb. This palace compound encapsulates much of the country's political and religious history between the mid-seventeenth century and the mid-nineteenth century, when Gondar was the capital of the Christian kingdom of Abyssinia.

\section{Statement of the problem}

Ethiopia is endowed with numerous sites of tourist attractions ranging from physical to cultural environment that are potentially important for the country's tourism development. Ethiopia has a unique feature of land in terms of natural, cultural, historical, and religious tourism assets and unique biodiversity, it has a big potential for tourism.

However, despite this high potentiality, tourism remains undeveloped due to various reasons. Ethiopia is earning very much less income than what its neighbors earn out of tourism though Ethiopia has a much higher potential tourism resource than these resources [8]. Ethiopia is characterized by low PCI $(\$ 100)$, severe unemployment, and absolute poverty. To eradicate or at least to reduce these problems, there arise a need for diversifying the economy from agricultural sector to the modern sector of industry and service. One of such modern service sector is tourism that we have high potentiality and that the sector has a high capacity for creating large number of jobs, income, solve the problems of Bops deficit, boost investment and development.

However the two opposite sides of Ethiopia, on one hand, a land of beauty with high potentiality and on the other hand, a country of poor and undeveloped have been experienced a large gap due to various reasons.

Thus, there is a need for the collaborative effort of government, NGOs, private sector and the local communities to develop the subsector and gain the benefits that are attributable to it which can solve or at least reduce the bad features of Ethiopia [9].

The various contributions of the tourism sector are not yet fully studied and not identified by government and/or other stakeholders in Gondar city. Therefore, the study was focus on assessing and analysing the roles of the tourism sector in Gondar city.

\section{Objective of the Study}

\section{General objective}

The general objective of the study was to assess and analyze the role of tourism to local economic development of Gondar city.

\section{Specific objectives}

The specific objectives of the study were:

- To assess the contribution of tourism to employment to the city.

- To assess the contribution of tourism to investment to the city.

- To assess the contribution of tourism to revenue generation and tourist flow to the city.

\section{Materials and Methods}

\section{Description of the study area}

Gondar, the capital of North Gondar Administrative Zone (NGAZ) is found at a road distance of $747 \mathrm{kms}$ north-west of Addis Ababa is the fourth populated urban center. Astronomically it is located at $12^{\circ} 30^{\prime}$ North and $37^{\circ} 20^{\prime}$ East (Ethiopian Mapping Agency, 1981). The city limits of Gondar city enclose an area of $40.27 \mathrm{~km}^{2}$ (CSA, 2010). The city is divided into 12 urban and 11 rural kebele administration units.

According to the classification used in Ethiopia, the climatic condition of the city is characterised as Woina Dega climatic zone. The mean annual ambient temperature of the city is between $18^{\circ} \mathrm{C}$ and $24^{\circ} \mathrm{C}$. The absolute maximum temperature usually occurs from March to May and the minimum temperature also occurs from June to November. Average annual rainfall is about $1308 \mathrm{~mm}$ (ibid).

The total population of the city is around 288,384 for the year 2009. The data also revealed that, the city has 47,720 households with an average family size of 5 persons. The average growth rate of the population is around $4.1 \%$. Of the total population $51.5 \%$ are female while the rest are male. Recently, Gondar is restructured as a metropolitan's city to make administrative effective and efficient by merging the previous 21 kebeles of the city into 12 city kebeles, 11 rural kebeles and 1 satellite kebele. City wise affairs are administered by mayors and other related city cabin members and council [10].

The economic sector of the city is mainly composed of industry, trade, service, tourism and urban agriculture. The economic contribution of the service sector to the city is also significant next to industry and trade.

\section{Sources and methods of data collection}

To obtain fruitful information that plays a key role in conducting and achieving the research objectives, the researcher used both primary and secondary sources. In a nut shell, to gather qualitative and quantitative information that contributed in achieving the objectives of the study the researcher used both primary and secondary source which are discussed below.

Primary sources of data: This study collected primary data using two main research methods of data collection. i.e., questionnaires and interviews.

Questionnaires: The Questionnaires are sought to provide large quantities of responses from a comparatively large number of people. To obtain first hand information on the issue; the researcher distributed and collected the questionnaires. The questionnaires included closeended questions, which help the respondents to select their answers from the alternative provided by the researcher, and open-ended questions that help respondents to respond their feeling freely [11-13] This questionnaire distributed to tourism offices, guidance associations and handicraft producers and sellers. 
Interviews: Interviews are made through the follow up of the leading questions. Face- to- face interviews carried out with the selected hotels where most tourists reside. The interview session conducted on one to one basis for each hotel [14].

Secondary sources of data: The main sources of data for this study is the secondary data collected from different secondary sources such as books, published and unpublished papers, bulletins pamphlets, research papers presented at workshops, documents related with tourism from various libraries, offices and internet [15].

\section{Methodology}

\section{Sample design}

In order to analyze the research question of this study, the researcher used more of descriptive research design.

There are two basic research methods, the qualitative and quantitative methods. Preferred methods for this study was both the qualitative and quantitative design that the study allow for the in depth analysis of the problem statement. It created discussions between the respondents and the researcher which allow gaining insights and direct understanding from the respondents. The combination of these two methods has overcome some of the limitations of using only one of the methods. As the purpose of the study is to assess the role of tourism on local economic development of Gondar city, qualitative and quantitative methods are chosen for elaborated results using questionnaires and interviews.

\section{Sample size}

Sample is one of the important part which leads to appropriate method of the study. The sample method that was used for this study was purposive sampling which is non- probability sampling and the simple random sampling method which is the probability sampling method.

The purposive sampling method is used because the population frame for this study contain only those directly impacted by the tourist arrivals. The sample frame include those employed in the concerned public offices, guide associations, handicraft producers and sellers, government employees, tourists and ten hotels where most of the tourists settle. Therefore, the sample size is 150 . Of this sample size 20 of the sample is taken from selected hotels managers as an interview, 90 samples is taken from guiders, handicraft producers and sellers and government employees and the remaining 40 was taken from domestic and international tourists.

\section{Data analysis}

The process of data analysis began after all data have been collected. Both primary and secondary data was organized in the same manner and analyzed using descriptive statistical tools. This includes statistical calculations, charts, tables and percentages to assess the role of tourism on local economic development of Gondar city. During the analysis stage, several interrelated information was summarized and arranged to make the analysis easily manageable.

\section{Results and Discussion}

\section{The role of tourism in Gondar city}

The role of tourism in employment creation in Gondar city: Tourism generates various employment opportunities for local residents at destinations. The employment opportunities generated through tourism in the destination areas can be grouped into three categories namely, direct, indirect and induced employment.

According to the tourism office, tourism provides money job opportunities to the dwellers of Gondar city. The number of employees engaged in hotels, restaurants, pensions, lodges etc. revealed that there are about 5500 persons employed in these hotels and many hotels are under construction that have a potential to provide over 4000 job opportunities. In Gondar city, tourism also created a job opportunity for more than 80 tour guides and operators, over 100 handicraft producers and sellers of souvenir goods, and more than 45 transportation service providers. Tourism also provided many job opportunities to government employees though there was difficulty in getting enough information about the exact number of employees.

The above Table 1 displays the increase in the number of employees in the tourism sector, especially employees in government organization in Gondar city. According to North Gondar information office, there were about 2000 employees in 2011 and increases to 4800 in 2015 which shows an increment on the number of employments in this sector and this figure excludes indirect employments.

The following Table 2 also shows the number and type of work department that tourism creates to employees in hotel industry.

Hotels are the most important vacations for tourism induced employment. Comparing government owned and private owned hotels, private owned hotels accounted for more than $73.3 \%$ of the total employment.

The above Table 2 also shows majority of the employees are engaged in restaurant and bar department both in the government and private owned hotels accounting for $59.2 \%$ and $69.5 \%$ respectively.

Tourism development and investment in Gondar city: In Gondar city, the tourism office and other concerned bodies try to encourage the involvement of the private sector through awareness creation about the impact of tourism sector as a means to enhance trade and investment. But the participation of these investors in the expansion of tourist facilities like standard hotels is low. Some investors are participating to support tourism through in construction of hotels and provision of hotel services, tour operation, car rental services, and shopping centers. According to North Gondar tourism office now there are 45 private travel agents and 35 joint travel agents and 50 tour operators.

\begin{tabular}{|l|l|l|l|l|l|}
\hline Year & 2011 & 2012 & 2013 & 2014 & 2015 \\
\hline Employees & 2000 & 2200 & 2500 & 3200 & 4800 \\
\hline
\end{tabular}

Source: North Gondar Information Office, 2015

Table 1: Number of employees in historical site preservation and government employees.

\begin{tabular}{|l|c|c|c|c|c|}
\hline \multirow{2}{*}{ Department } & \multicolumn{2}{|c|}{ Number of employee in } & Total & \multicolumn{2}{|c|}{ Percentage of total in } \\
\cline { 2 - 6 } & Government & Private & & Government & Private \\
\hline $\begin{array}{l}\text { Management and } \\
\text { administration }\end{array}$ & 200 & 370 & 570 & 13.6 & 9.2 \\
\hline $\begin{array}{l}\text { Housekeeping and } \\
\text { laundry }\end{array}$ & 160 & 320 & 480 & 10.9 & 7.9 \\
\hline $\begin{array}{l}\text { Service and } \\
\text { maintenance }\end{array}$ & 150 & 340 & 490 & 10.2 & 8.4 \\
\hline Bar and restaurant & 870 & 2800 & 3670 & 59.2 & 69.5 \\
\hline Other services & 90 & 200 & 290 & 6.1 & 5 \\
\hline Total & 1470 & 4030 & 5500 & & \\
\hline
\end{tabular}

Source: North Gondar Culture and Tourism office, 2015

Table 2: Structure of employment in the hotel industry. 
It is known that Gondar is known by its historical attraction sites and cultures, and it attracts many tourists inside and outside the country. To keep its fascination, the city involves various private sectors to develop accommodation services, transportation, local tour guides etc. Many investors are trying to buy land to take the opportunities of demand for commerce and services around the main market which may help to develop tourism. Previously there were only few hotels that can provide better tourist services than the other hotels in the city, Quara hotel, Terara Hotel, Fogera hotel and Goha hotel. Since the demand for investment on tourism is increasing the city's office of services is trying to fulfill this demand.

As we can understand from the above Table 3, the demand to involve in investment on the tourism sector increases from 2010 to 2013, particularly, in hotel expansion and recreational areas and parks and lodges. The other tourist facilities; theatre halls and art galleries did not receive appropriate attention by the private sector. But in 2014 and 2015 many hotels are under construction and it is believed it can provide better services to visitors.

To develop and facilitate the tourism sector and to provide the services that the tourists require, the government has open tourism offices in the city.

The city provides some standard and recommended hotels and pensions to tourists though the price for getting these services differ for different tourists. The tourism office prepare a pamphlet that center information on the list of hotels, pensions, traditional night clubs, police stations, bus stations, health centers, super markets, internet service areas, travel agencies, banking services, souvenir shops, historical sites, therefore, this pamphlet and other documents helps the tourists to indicate where there services are available.

The state expands the infrastructure facilities to different historical sites of the city. The three most known historical sites of Gondar city i.e., Fasil Castle, Qusquam and Debre berhan Sellassie had electric power facility, asphalted road that connect these sites to other parts of the city and In the city there are many shopping centers which locate in and outside hotels to provide various services. Souvenir shops are also developed to provide cultural closes, artifacts, gifts etc.

Generally telephone services are available, as per the response of the officials of the tourism office, the city provides many services to the tourists who came to the city. There are some services which the city is unable to provide to visitors.

The role of tourism in income and tourist flow to Gondar city: Since Gondar is the most known city in its historical sites, tourists flow to the city for different purposes. During their stay in the city, they expense more to the services they require. At the same time the expense of these tourists is an income to the city. The classification of tourists by the purpose of visit reveals that vacation tourists, research tourists, business tourists, transit passengers, and voluntary service providing tourists are important components of tourism to Gondar city.

\begin{tabular}{|l|c|c|c|c|}
\hline Tourist facilities & $\mathbf{2 0 1 0}$ & $\mathbf{2 0 1 1}$ & $\mathbf{2 0 1 2}$ & $\mathbf{2 0 1 3}$ \\
\hline Tourist serving hotels & 22 & 25 & 27 & 35 \\
\hline Recreational area and parks & 5 & 8 & 10 & 13 \\
\hline Theatre and meeting halls & - & - & 3 & 8 \\
\hline Souvenir shops & 2 & - & 7 & 15 \\
\hline Art Galleries & - & - & - & - \\
\hline Lodges & 2 & - & 7 & 9 \\
\hline
\end{tabular}

Source: North Gondar Culture and Tourism Office, 2015

Table 3: Trend of development of tourist facilities in Gondar.
The following Figure 1 shows the number of international tourists by purpose of visits.

The above Figure 1 tries to provide the necessary information about the number of international tourists that flow to Gondar city. If we put the classification by percentage, it shows that vacation tourists accounted for $75 \%$, research tourists accounted for $7 \%$, business tourists for $3 \%$, transit passengers accounted for $2 \%$ and tourists for voluntary purpose accounted for $2 \%$ and others which are not stated accounted for $11 \%$. Therefore, the city receives much of its income from tourists coming to vacation purpose as it covers $75 \%$ of the total international tourist flow.

It is also possible to see the number of international tourists from another angle, i.e., the number of tourists from their nationality.

The above Table 4 displays U.K is the dominant international tourist inflow to Gondar accounting for $31.5 \%$. The second large share of international tourists comes from Holland which accounted for $15.3 \%$ and this is because of most of the tourists who came from Holland come for the purpose of research and practical attachment. The third large share of tourist inflow comes from France accounting $13.7 \%$ which is followed by America (10.4\%) and Germany (9\%). $18 \%$ of the tourists come to Gondar city from different countries which are not stated yet. Therefore, UK, Holland and France accounted $60.5 \%$ of the total international tourist inflow of Gondar city in 2015.

To identify the income from tourism, it is better to see the income receipts from both international and domestic tourist arrivals. Therefore, the following Table 3 insights these fact.

As the above Table 5 indicates the number of foreign and domestic tourists is increasing from year to year. The domestic tourists were

Number of international tourists
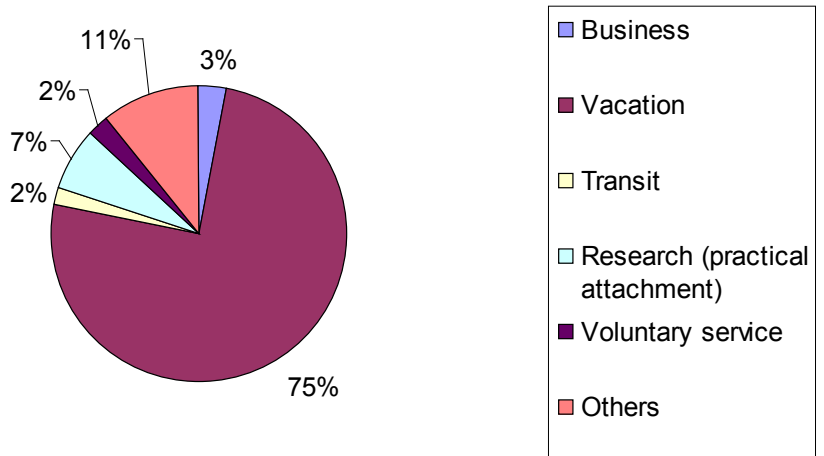

Source: North Gondar Culture and tourism office, 2015

Figure 1: Number of international tourists in 2015 by purpose of visit.

\begin{tabular}{|l|c|c|}
\hline Nationality & $\begin{array}{c}\text { Number of international } \\
\text { tourists }\end{array}$ & Percentage \\
\hline America & 3325 & 10.4 \\
\hline U.K & 10042 & 31.5 \\
\hline France & 4358 & 13.7 \\
\hline Germany & 3538 & 9 \\
\hline Holland & 4875 & 15.3 \\
\hline Others not stated & 5701 & 18 \\
\hline Total & 31,839 & 100 \\
\hline Source: North Gondar Culture and tourism office, 2015 \\
\hline
\end{tabular}

Table 4: International tourist inflow by nationality (2015). 


\begin{tabular}{|c|c|c|c|c|}
\hline \multirow[t]{2}{*}{ Year } & \multicolumn{2}{|c|}{ Number of tourists } & \multicolumn{2}{|c|}{ Income from tourists } \\
\hline & Domestic & Foreign & Domestic & Foreign \\
\hline 2007 & 13394 & 5081 & 80,000 & 300,000 \\
\hline 2008 & 16539 & 5142 & 99,301 & 544,880 \\
\hline 2009 & 19665 & 8325 & 158,480 & 662,922 \\
\hline 2010 & 24,595 & 11,647 & 330,005 & 847,300 \\
\hline 2011 & 29,784 & 17,443 & 485,704 & $1,249,025$ \\
\hline 2012 & 39,693 & 19546 & 560,871 & $1,913,500$ \\
\hline 2013 & 42,973 & 22,969 & 770,061 & $2,678,360$ \\
\hline 2014 & 48,216 & 28,428 & 920,546 & $4,986,944$ \\
\hline 2015 & 61,048 & 31,839 & $1,230,000$ & $7,768,019$ \\
\hline
\end{tabular}

Table 5: Income receipts and international and domestic tourist arrivals of Gondar city from 2007-2015.

13394 in 2007 but it raised to 61,048 in 2015 and the number of foreign tourists has increased from 5081 in 2007 to 31,839 in 2015. As to the income receipt from those tourists the trend shows that it is also increasing. The entrance fee for domestic visitors is low as compared to the payments paid by foreign tourists. For example the entrance fee to visit Fasil Castle for domestic visitors is 5 birr for students and 20 birr for others if they do not have photographic and video camera. If one uses photographic and video camera he need to pay 30 birr. Many students through "know your country "(Agerken Ewok), sport festivals do not pay to entry. But the entrance fee for foreign visitors is 150 birr, therefore the difference is high.

Domestic visitors are highest during July to September because during this period the graduation ceremonies of the universities are celebrated.

International tourist arrivals reach it peach point in 2015. These tourists are flowing to the city between Decembers to January due to religious events or festivals are celebrated in these months. Epiphany or locally known as "Timket", Christmas and carnivals are the most known and fascinating religious events in Ethiopia and these live culture of the country attracts many international tourists. The other reason for the highest number of international arrivals in these months is the winter season of the western world where majority of Ethiopia's visitors originates.

\section{Conclusion and Recommendation}

\section{Conclusion}

The general objective of the study was to assess the role of the tourism sector to local development of Gondar city. Tourism sector like any other sectors contribute for development endeavor of our country. More specifically the sector benefits our country via creation of employment opportunity and income generation activities for the society.

As it is discussed in the previous chapter, tourism grew from time to time and as a result, the numbers of visitors coming to Gondar city are increasing which results in various benefits to be accrued by the city.

Tourism has a number of impacts like economic, cultural, social and environmental. Considering its economic impacts, it has a number of merits like generating foreign exchange, contributes to raise GDP and employment, motivates the investment and development, accelerates the expansion of infrastructural facilities to the locals, increases the demand for locally produced goods and services which in turn motivates domestic investors to invest their capital in the economy, etc. Generally, it has various direct, indirect and induced impacts that through the multiplier effect accelerates the economic growth.
The study finding indicates that tourism sector is crucial armed force in fighting and reducing the extent and intensity of poverty in general. Besides, the society`s livelihoods were improved significantly. More specifically, the employment of those who joined the sector as government employee has increased from 2000 employees in 2011 and increases to 4800 in 2015 and the number of employees engaged in hotels, restaurants, pensions, lodges etc. revealed that there are about 5500 persons employed excluding other indirect employees and the income level increased from birr 80,000 and birr 300,000 in 2007 to birr 1,230,000 and 7,768,019 in 2015 from domestic and foreign tourists respectively.

However, comparing to the potential that Ethiopia had and its neighboring countries, it lag behind in accruing the appropriate benefits that it have to have. The contribution made by the sector to the economic development of the country did not contribute as much as what is expected from it due to various reasons.

\section{Recommendation}

Based on the findings of the study and conclusions made the following recommendations were forwarded.

- The Government should do a lot on how trained personnel are to be produced in the right number, in the needed specializations and occupations.

- Tourism development should be community oriented.

- Special emphasis should be given the statistical measurements of tourism.

- To make tourism able to solve the balance of payments problems, government should follow promotional policies (overseas promotion) and development policies (infrastructure development).

- There should be focus on revitalized facilities to provide quality services and experiences, enhanced attractions, upgraded hotels, and improved roads and air ports.

- Emphasis should be given to protect and preserve historical places and cultural heritages.

- Tourists should not be prohibited o use a photograph and film and again should not be asked additional fee to do so. This will advertise our tourist attractions to the outside world and encourage more tourists to come to the city.

Encouraging private investment in the hospitality industry by providing incentives like reduction of tax on import goods, providing loan and insurance services are very important. 
Citation: Nurhssen S (2016) The Role of Tourism on Local Economic Development of Gondar City, Amhara Regional State, Ethiopia. J Glob Econ 4: 207. doi: 10.4172/2375-4389.1000207

\section{References}

1. Bosselman, Peterson, Cartheny Mc (1993) Managing Tourism Growth. Islands Press, Washington D.C.

2. World Tourism Organization (2015) UNWTO Tourism Highlights: UNWTO. Madrid.

3. Bovy B, Lawson (1998) Tourism and Recreation Handbook of Planning and Design. Bath Press, Great Britain.

4. (2015) WTTC Travel and Tourism Economic Impact.

5. Over Seas Development Institute Briefing Paper (2012) Can Tourism Offer ProPoor Pathways to Prosperity?

6. Matheson, Wall (1982) New directions in tourism for Third World Development.

7. Central Statistical Authority of Ethiopia (2010) Population and Housing Census of Ethiopia: Statistical Report for Amhara Region.
8. Jamieso, Goodwin H, Edmunds C (2004) Contribution of Tourism on Poverty Alleviation: Pro- Poor Tourism and the Challenge of Measuring Impacts. UNESCAP.

9. Atlabachew T (2010) The Importance of Sustainable Tourism Development.

10. World Tourism Barometer (2007) World Tourism Organization.

11. Mann S, Addis S (2006) A Medium Term Strategy to Develop Tourism in Ethiopia. World Bank African Region. Ethiopia.

12. World Tourism Organization (1995) Concepts, Definitions and Classification for Tourism Statistics. Spain.

13. WTO, USAID, World Bank (2006) Communication and Sustainable Tourism

14. The Economic Times (2008) Paris: Most Visited and Most Expensive City in the world.

15. Joshua K (2005) The True Meaning of Tourist Trap. The Washington Post. 